\title{
antioxidants
}

ISSN 2076-3921

www.mdpi.com/journal/antioxidants

Article

\section{Antioxidant Potential of Bark Extracts from Boreal Forest Conifers}

\section{Jean Legault *, Karl Girard-Lalancette, Dominic Dufour and André Pichette}

Laboratoire d'analyse et de séparation des essences végétales (LASEVE), Département des Sciences fondamentales, Université du Québec à Chicoutimi (UQAC), 555, boulevard de l'Université, Chicoutimi, Québec G7H 2B1, Canada; E-Mails: karl.lalancette@gmail.com (K.G.-L.); dominicdufour@gmail.com (D.D.); andre.pichette@uqac.ca (A.P.)

* Author to whom correspondence should be addressed; E-Mail: Jean_Legault@uqac.ca; Tel.: +1-418-545-5011 (ext. 2334); Fax: +1-418-545-5012.

Received: 6 May 2013; in revised form: 13 June 2013 / Accepted: 28 June 2013 /

Published: 11 July 2013

\begin{abstract}
The bark of boreal forest conifers has been traditionally used by Native Americans to treat various ailments and diseases. Some of these diseases involve reactive oxygen species (ROS) that can be prevented by the consumption of antioxidants such as phenolic compounds that can be found in medicinal plants. In this study, ultrasonic assisted extraction has been performed under various solvent conditions (water:ethanol mixtures) on the bark of seven boreal forest conifers used by Native Americans including: Pinus strobus, Pinus resinosa, Pinus banksiana, Picea mariana, Picea glauca, Larix laricina, and Abies balsamea. The total phenolic content, as well as ORAC $\mathrm{FL}_{\mathrm{FL}}$ potency and cellular antioxidant activity $\left(\mathrm{IC}_{50}\right)$, were evaluated for all bark extracts, and compared with the standardized water extract of Pinus maritima bark (Pycnogenol), which showed clinical efficiency to prevent ROS deleterious effects. The best overall phenolic extraction yield and antioxidant potential was obtained with Picea glauca and Picea mariana. Interestingly, total phenolic content of these bark extracts was similar to Pycnogenol but their antioxidant activity were higher. Moreover, most of the extracts did not inhibit the growth of human skin fibroblasts, WS1. A significant correlation was found between the total phenolic content and the antioxidant activity for water extracts suggesting that these compounds are involved in the activity.
\end{abstract}


Keywords: phenolic content; ORAC; antioxidant cell-based assay; Pinus banksiana; Pinus resinosa; Pinus strobus; Picea glauca; Picea mariana; Larix laricina; Abies balsamea

\section{Introduction}

Native Americans used the plants of the boreal forest to treat various ailments and diseases [1]. The bark of several conifers, such as Pinus strobus (white pine), Picea glauca (white spruce), Larix laricina (Larch tamarack), and Abies balsamea (balsam fir) was used. The bark was prepared as decoctions, infusions or poultices to treat gonorrhea, tuberculosis, diarrhea, pain, cold, kidney troubles, burns, inflammation, and rheumatoid arthritis [1-6]. However, bark was mainly used for cough relief $[1,2,7]$. Moreover, some species were used as an expectorant to treat breathing difficulties (Pinus strobus, Picea glauca), and persistent cough (Larix laricina) [1].

Reactive oxygen species (ROS) have been implicated in several diseases and symptoms for which conifer bark was used, in particular inflammation [8,9] and rheumatoid arthritis [10]. ROS also play a role in chronic obstructive pulmonary diseases (COPD) [11,12]. The COPD are characterized by the secretion of mucus, breathing difficulties and persistent coughing. Interestingly, the consumption of polyphenolic compounds showed to be beneficial to relieve COPD [13-16]. The water extract of Pinus maritima bark (pycnogenol) is rich in phenolic compounds, mainly procyanidins and phenolic acids, and possesses a strong free radical-scavenging activity against ROS [17]. Pycnogenol has been reported to increase plasma antioxidant capacity and to significantly improve pulmonary functions and asthma symptoms $[18,19]$. In spite of the strong potential of bark extracts from boreal forest conifers, the total phenolic content and the antioxidant activity for several of them are poorly studied. In 2009, Diouf et al., reported antioxidant and anti-inflammatory activities of hot water extract from Picea mariana bark [20]. In addition, Garcia-Pérez et al., (2010) reported antioxidant and anti-proliferative properties of bark extracts from Picea mariana on normal and psoriatic keratinocytes [21]. More recently, Royer et al., (2013) suggested that Pinus banksiana and Picea mariana barks possess an anti-aging potential due to their antioxidant, anti-enzymatic and antimicrobial activities [22].

In this study, we report the total phenolic content of bark extracts from seven pinaceae of the boreal forest, including Pinus banksiana (Lamb.), Pinus resinosa (Aiton), Pinus strobus (L.), Picea glauca (Moench), Picea mariana (Mill), Larix laricina (Du Roi) and Abies balsamea (L.). The antioxidant activity of conifer bark extracts was also evaluated using $\mathrm{ORAC}_{\mathrm{FL}}$ and a cell-based antioxidant assay. The results are compared with Pycnogenol, a standardized bark extract of Pinus maritima.

\section{Experimental Section}

\subsection{Chemicals}

6-Hydroxy-2,5,7,8-tetramethylchroman-2-carboxylic acid (97\%) (Trolox), 2,2'-Azobis(2methylpropionamidine) dihydrochloride (97\%) (AAPH), Folin-Ciocalteu phenol reagent (FC), sodium carbonate decahydrate (99.5\%), Fluoresceine disodium salt (FL), dichlorofluorescin diacetate (97\%) (DCFH-DA), tert-butyl hydroperoxyde (70\%) $(t$-BuOOH), resazurin $(92 \%)(\mathrm{Rz})$, and Hoescht $(95 \%)$ 
(Ho), were all purchased from Sigma-Aldrich (Oakville, Ontario, Canada). Pycnogenol was produced by Swiss Herbal Remedies Ltd. (Richmond Hill, Ontario, Canada), with standardized potency of $85 \%$ proanthocyanidins. Pycnogenol tablets contain $25 \mathrm{mg}$ of Pinus maritima extract and also contain dicalcium phosphate, microcrystalline cellulose and magnesium stearate. Tablets were grinded and extracted $1 \mathrm{~h}$ with $5 \mathrm{~mL}$ of water.

\subsection{Plant Material and Preparation of Crude Bark Extract}

All conifer bark specimens were harvested in June 2005 near station Simoncouche in the Réserve faunique des Laurentides, Québec, Canada. The specimens were identified by Patrick Nadeau, and deposited to herbarium of Saguenay-Lac-Saint-Jean (Département des Sciences Fondamentales; Université du Québec à Chicoutimi). Barks were dried at room temperature then powdered and stored at $-20{ }^{\circ} \mathrm{C}$. All extractions were ultrasonic assisted using a Sonifier Cell disruptor 350 (BRANSON Ultrasonics Corporation), with output control set at 7/10, and performed with $25 \mathrm{~g}$ of bark powder in $375 \mathrm{~mL}$ of solvent for $30 \mathrm{~min}$. Extraction mixtures were constantly mixed with a magnetic agitator and were maintained at $30{ }^{\circ} \mathrm{C}$. Each bark sample was extracted in parallel with five different solvent conditions: ethanol:water [0:100], [25:75], [50:50], [75:25], [100:0]. Extraction mixtures were then filtered and dried under vacuum at room temperature for 3 days up to constant weight.

\subsection{Dosing of Total Phenol Content}

The total phenolic content was determined using the Folin-Ciocalteu reagent according to the procedure reported by Singleton and Rossi [23], with some modifications. Briefly, a volume of $50 \mu \mathrm{L}$ containing growing concentrations of extract ranging from 0.39 to $50 \mathrm{mg} / \mathrm{mL}$ were mixed with $25 \mu \mathrm{L}$ of 1:2 water diluted Folin-Ciocalteu reagent in transparent flat-bottom 96-well plates (NUNC). All manipulations were performed in a light shielded environment. After 5 min of reaction, $125 \mu \mathrm{L}$ of sodium carbonate decahydrate solution $(20 \mathrm{~g} / 100 \mathrm{~mL})$ was added to each well. Absorbance was then measured at $758 \mathrm{~nm}$ using an automated Varioskan Ascent plate reader (Thermo Electron). Analysis was performed in triplicate, and the results were expressed in gallic acid equivalents.

\subsection{ORAC $C_{F L}$ Assay}

The procedure was modified from the method described by Ou et al. [24]. Briefly, the ORAC assay was carried out in black round-bottom 96-well plate (Costar) on a Fluoroskan Ascent Fl ${ }^{\mathrm{TM}}$ plate reader (Labsystems). Trolox was used as a control standard. The experiment was conducted at $37.5{ }^{\circ} \mathrm{C}$ and $\mathrm{pH} 7.4$, with a blank sample in parallel. The fluorimeter was programmed to record the fluorescence of fluorescein every $60 \mathrm{~s}$ after addition of 2,2'-azobis (2-amidinopropane) dihydrochloride (AAPH). The final results were calculated by comparing the net areas under the fluorescein decay curves between the blank and the samples. ORAC values were expressed in micromoles of Trolox equivalents (TE) per milligram ( $\mu \mathrm{mol} \mathrm{TE} / \mathrm{mg}$ ). 


\subsection{Cell Culture}

The murine fibrosarcoma L-929 (ATCC \#CCL-1) and human skin fibroblasts WS1 (ATCC \# CRL-1502) cell line were obtained from the American Type Culture Collection (ATCC, Manassas, USA). They were grown in Minimum Essential Medium with Earle's salts supplemented with 10\% fetal calf serum (Hyclone, Logan, USA), solution of vitamins $(1 \times)$, sodium pyruvate $(1 \times)$, non-essential amino acids $(1 \times)$, penicillin $(100 \mathrm{IU})$ and streptomycin $(100 \mu \mathrm{g} / \mathrm{mL})\left(\right.$ Mediatech Cellgro $\left.{ }^{\circledR}\right)$. Cells were cultured in a humidified atmosphere at $37{ }^{\circ} \mathrm{C}$ in $5 \% \mathrm{CO}_{2}$.

\subsection{Antioxidant Cell-Based Assay}

Antioxidant activity was evaluated using the DCFH-DA assay as described previously [25], with some modifications. Briefly, L-929 cells were plated in 96-well plates at 10,000 cells per well and incubated for $24 \mathrm{~h}$ at $37{ }^{\circ} \mathrm{C}$ and $5 \% \mathrm{CO}_{2}$. The cells were washed with $150 \mu \mathrm{L}$ Hank's balanced salt solution (HBSS) at pH 7.4 and incubated for 30 min with $100 \mu \mathrm{L}$ HBSS (pH 7.4) containing $5 \mu \mathrm{M}$ DCFH-DA. The cells were then washed again with $150 \mu \mathrm{L}$ HBSS. To assess the antioxidant activity, the cells were incubated with a growing concentration of extract $(0.2-200 \mu \mathrm{g} / \mathrm{mL})$, in the absence or presence of $200 \mu \mathrm{M}$ tert-butylhydroperoxide $(t-\mathrm{BuOOH})$. The final concentration of extraction solvent in the culture medium was maintained at $0.5 \%$ (volume/volume) to avoid solvent toxicity. Fluorescence was measured after $1 \mathrm{~h}$ and $4 \mathrm{~h}$ on the automated plate reader (Fluoroskan Ascent FL ${ }^{\mathrm{TM}}$, Labsystems) using an excitation wavelength of $485 \mathrm{~nm}$ and an emission wavelength of $530 \mathrm{~nm}$. Antioxidant activity is expressed as the concentration of extract inhibiting $50 \%$ of DCFH oxidation $\left(\mathrm{IC}_{50}\right)$.

\subsection{Cytotoxicity Assay}

Exponentially growing WS1 cells were plated in flat-bottom 96-well microplates (Costar, Corning Inc.) at a density of $5 \times 10^{3}$ cells per well in $100 \mu \mathrm{L}$ of culture medium and were allowed to adhere for $16 \mathrm{~h}$ before treatment. Increasing concentrations of extract $(1.5-200 \mu \mathrm{g} / \mathrm{mL})$ in their respective extraction solvent were then added $(100 \mu \mathrm{L}$ per well). The final concentration of ethanol in the culture medium was maintained at $0.5 \%$ (volume/volume) to avoid solvent toxicity. The cells were incubated for $24 \mathrm{~h}$ in the presence or absence of bark extract. Cytotoxicity was assessed using the resazurin reduction test [26]. Fluorescence was measured on an automated Fluoroskan Ascent FL ${ }^{\mathrm{TM}}$ plate reader (Labsystems) using excitation and emission wavelengths of $530 \mathrm{~nm}$ and $590 \mathrm{~nm}$, respectively. Cytotoxicity is expressed as the lowest concentration of tested extract inhibiting $20 \%$ or more of cell growth in comparison with untreated cells.

\subsection{Statistical Analysis}

Data were expressed as means \pm standard deviation from at least three determinations $(n \geq 3)$. Comparisons between groups were performed using Kruskal-Wallis one way analysis of variance on ranks, with pairwise comparison by Student-Newman-Keuls method. P values of 0.05 or less were considered as statistically significant. Relationship between ORAC, $\mathrm{IC}_{50}$ and total phenolic content were determined using Pearson correlation, followed by linear regression. All statistical analysis were done with SigmaStat 3.5 and Microsoft Excel. 


\section{Results and Discussion}

In this study, various extracts of bark from boreal forest conifers were evaluated for their total phenolic content and antioxidant potency. The tested conifers were: Pinus banksiana, Pinus resinosa, Pinus strobus, Picea glauca, Picea mariana, Larix laricina and Abies balsamea. The antioxidant activity and total phenolic content were compared with a standardized water extract of Pinus maritima bark (pycnogenol) recognized as having a strong antioxidant activity. The main constituents of pycnogenol are phenolic compounds, including monomers (catechin, epicatechin and taxifolin), and condensed flavanoids (procyandins and proanthocyanidins) [17]. Pycnogenol also contains phenolic acids, such as caffeic, ferulic, and p-hydroxybenzoic acids [17].

\subsection{Extraction Yield, Total Phenol Content and Cytotoxicity of Various Conifer Bark Extracts}

The bark of each conifer was extracted using sonication with five solvent conditions including water:ethanol [100:0]; [75:25]; [50:50]; [25:75]; [0:100]. The total extraction yields, presented in Table 1, show that the extracted quantity ranged from 5 to $30 \mathrm{~g}$ for $100 \mathrm{~g}$ of powdered bark. The total phenolic content of bark extracts were evaluated using Folin-Ciocalteu assay. This method allows to measure phenolic and polyphenolic compounds such as phenolic acids, flavonoids, and tannins. The results, expressed as grams of total phenolic compounds (gallic acid equivalent) for $100 \mathrm{~g}$ of extract, are presented in Table 1. Pycnogenol was used as a positive control with total gallic acid equivalent phenolic content of $48 \pm 5 \mathrm{~g}$ per $100 \mathrm{~g}$ of extract while Ustun et al., 2012 reported a concentration of about $57 \mathrm{~g} / 100 \mathrm{~g}$ [27]. Of all the tested species of conifer barks, Pinus resinosa-[50:50], Picea glauca-[100:0] and Picea mariana-[75:25] were found the richest in phenolic compounds with respectively $61 \pm 4 \mathrm{~g}, 59 \pm 5 \mathrm{~g}$ and $55 \pm 6 \mathrm{~g}$ per $100 \mathrm{~g}$ of extract. These values are similar to Pycnogenol. For the other tested species, the highest total phenol content measured in the extracts were in the following order: Pinus banksiana-[25:75] (45 $\pm 1 \mathrm{~g} / 100 \mathrm{~g})$, Larix laricina-[100:0] (34 $\pm 2 \mathrm{~g} / 100 \mathrm{~g})$, Abies balsamea-[50:50] (32 $\pm 2 \mathrm{~g} / 100 \mathrm{~g})$ and Pinus strobus-[75:25] (26 $\pm 1 \mathrm{~g} / 100 \mathrm{~g})$. The cytotoxicity of all bark extracts was evaluated on human skin fibroblast WS1. The cells were incubated in the presence or absence of growing concentrations of extracts for $24 \mathrm{~h}$. In Table 1, the results show that all extracts, with the exception of the Larix laricina-[75:25] extract, do not inhibit cell growth in doses of $50 \mu \mathrm{g} / \mathrm{mL}$ and less, indicating that the extracts are not cytotoxic for WS1 in these dose ranges. For the Picea mariana and Pinus banksiana extracts, no cytotoxicity was found in doses as high as 100 to $200 \mu \mathrm{g} / \mathrm{mL}$. Royer et al., reported no cytotoxicity of hot water extract of Picea mariana on normal keratinocytes at concentrations lower than $55 \mu \mathrm{g} / \mathrm{mL}$ [21].

The extraction yields and phenolic contents of bark extracts from three species of this study (Abies balsamea, Pinus banksiana, Picea mariana) has been reported previously by another research group which used different extraction methods such as hot water reflux and ethanol maceration [21,22]. In comparison with their results, the overall ultrasonic assisted bark extraction yield obtained with Abies balsamea and Pinus banksiana, considering all water-ethanol extraction conditions, has been lower than yields they obtained using $1 \mathrm{~h}$ hot water reflux but similar to ethanol maceration $[21,22]$. However, ultrasonic assisted Picea mariana bark extraction resulted in higher extraction yield than both other methods. In terms of phenolic content richness, short ultrasonic assisted extraction provides 
better recovery than hot water reflux and ethanol maceration, except for Abies balsamea which result in lower total phenolic content [21,22].

Table 1. Total extraction yield, extract phenolic content and cytotoxicity.

\begin{tabular}{|c|c|c|c|c|}
\hline Conifer species & $\begin{array}{c}\text { Extraction conditions } \\
\text { (water:ethanol) }\end{array}$ & $\begin{array}{c}\text { Extraction yield }{ }^{\text {a }} \\
(\mathrm{g} / \mathbf{1 0 0} \mathrm{g})\end{array}$ & $\begin{array}{c}\text { Extract Phenolic } \\
\text { content (g GAE/100 g) }\end{array}$ & $\begin{array}{l}\text { Cytotoxicity } \\
(\mu \mathrm{g} / \mathrm{mL})^{\mathrm{c}}\end{array}$ \\
\hline \multirow{5}{*}{ Pinus banksiana } & $100: 0$ & 9 & $27 \pm 2$ & $>100$ \\
\hline & $75: 25$ & 11 & $30 \pm 2$ & $>100$ \\
\hline & $50: 50$ & 12 & $37 \pm 4$ & $>100$ \\
\hline & $25: 75$ & 13 & $45 \pm 1$ & $>200$ \\
\hline & $0: 100$ & 15 & $23 \pm 1$ & $>100$ \\
\hline \multirow{5}{*}{ Pinus resinosa } & $100: 0$ & 5 & $37 \pm 4$ & $>200$ \\
\hline & $75: 25$ & 7 & $61 \pm 6$ & $>100$ \\
\hline & $50: 50$ & 7 & $61 \pm 4$ & $>100$ \\
\hline & $25: 75$ & 11 & $46 \pm 3$ & $>100$ \\
\hline & $0: 100$ & 10 & $42 \pm 5$ & $>50$ \\
\hline \multirow{5}{*}{ Pinus strobus } & $100: 0$ & 7 & $21 \pm 3$ & $>50$ \\
\hline & $75: 25$ & 9 & $26 \pm 1$ & $>200$ \\
\hline & $50: 50$ & 15 & $22 \pm 1$ & $>50$ \\
\hline & $25: 75$ & 9 & $15 \pm 2$ & $>50$ \\
\hline & $0: 100$ & 9 & $10 \pm 1$ & $>50$ \\
\hline \multirow{5}{*}{ Picea glauca } & 100:0 & 17 & $59 \pm 5$ & $>100$ \\
\hline & $75: 25$ & 21 & $51 \pm 4$ & $>100$ \\
\hline & $50: 50$ & 24 & $55 \pm 9$ & $>50$ \\
\hline & $25: 75$ & 29 & $36 \pm 4$ & $>200$ \\
\hline & $0: 100$ & 26 & $48 \pm 5$ & $>100$ \\
\hline \multirow{5}{*}{ Picea mariana } & $100: 0$ & 14 & $50 \pm 5$ & $>200$ \\
\hline & $75: 25$ & 17 & $55 \pm 6$ & $>100$ \\
\hline & $50: 50$ & 23 & $48 \pm 4$ & $>200$ \\
\hline & $25: 75$ & 24 & $46 \pm 5$ & $>200$ \\
\hline & $0: 100$ & 23 & $43 \pm 3$ & $>100$ \\
\hline \multirow{5}{*}{ Larix laricina } & $100: 0$ & 11 & $34 \pm 2$ & $>50$ \\
\hline & $75: 25$ & 15 & $27 \pm 2$ & $>12.5$ \\
\hline & $50: 50$ & 24 & $29 \pm 3$ & $>50$ \\
\hline & $25: 75$ & 30 & $26 \pm 3$ & $>50$ \\
\hline & $0: 100$ & 30 & $29 \pm 3$ & $>50$ \\
\hline \multirow{5}{*}{ Abies balsamea } & $100: 0$ & 7 & $6 \pm 1$ & $>100$ \\
\hline & $75: 25$ & 9 & $21 \pm 1$ & $>100$ \\
\hline & $50: 50$ & 7 & $32 \pm 2$ & $>100$ \\
\hline & $25: 75$ & 17 & $21 \pm 2$ & $>50$ \\
\hline & $0: 100$ & 20 & $20 \pm 1$ & $>50$ \\
\hline
\end{tabular}

${ }^{\mathrm{a}}$ Total extraction yield from $100 \mathrm{~g}$ of dry powdered conifer bark. ${ }^{\mathrm{b}}$ Grams of total phenolic compounds (gallic acid equivalent) for $100 \mathrm{~g}$ of extract. ${ }^{\mathrm{c}}$ The concentration of conifer bark extract $(\mu \mathrm{g} / \mathrm{mL})$ is considered cytotoxic when it inhibits cell growth $>20 \%$ in comparison with untreated cells. 


\subsection{Evaluation of Antioxidant Activity of Extracts Using ORAC $C_{F L}$ and Cell-Based Assay}

The antioxidant activity of bark extracts was evaluated using ORAC and a cell-based assay. ORAC $_{\mathrm{FL}}$ values are expressed as Trolox equivalent ( $\mu \mathrm{mol}$ ) by $\mathrm{mg}$ of extracts, and cell-based assays are expressed as the concentration inhibiting fifty percent $\left(\mathrm{IC}_{50}\right)$ of tert-butylhydroperoxide $(t-\mathrm{BuOOH})$ induced oxidation of 2',7'-dichlorofluorescin (DCFH). Pycnogenol was used as a positive control with an $\mathrm{ORAC}_{\mathrm{FL}}$ value of $5.4 \pm 0.3 \mu \mathrm{mol} \mathrm{TE} / \mathrm{mg}$ and $\mathrm{an} \mathrm{IC}_{50}$ of $1.5 \pm 0.2 \mu \mathrm{g} / \mathrm{mL}$. This result is slightly lower than ORAC values (6.5 to $7.7 \mu \mathrm{mol} \mathrm{TE} / \mathrm{mg}$ ) reported by Dudonné et al., 2009 [28]. Results presented in Figure 1 show that $\mathrm{ORAC}_{\mathrm{FL}}$ values of all extracts ranged from 2.4 to $29 \mu \mathrm{mol} \mathrm{TE} / \mathrm{mg}$, while cell-based assay $\mathrm{IC}_{50}$ values ranged from 5.2 to $0.3 \mu \mathrm{g} / \mathrm{mL}$. The Pinus resinosa-[50:50] possesses the highest $\mathrm{ORAC}_{\mathrm{FL}}$ value with $29 \mu \mathrm{mol} \mathrm{TE} / \mathrm{mg}$. According to the cell-based assay, the results show that the extracts of Pinus banksiana-[50:50] and [25:75], Picea mariana-[75:25] and Picea glauca-[100:0], have a higher antioxidant activity with an $\mathrm{IC}_{50}$ smaller than $0.4 \mu \mathrm{g} / \mathrm{mL}$. The correlation between ORAC $_{\mathrm{FL}}$ and cell-based assay for all species is weak but significant $(P<0.05)$ with a coefficient of determination $R^{2}$ of 0.24 . This weak correlation between both methods can possibly be explained by the cellular context of cell-based assay which is not present in ORAC assay.

Figure 1. Antioxidant activity of conifer bark extracts using (A) ORAC assay and (B) cell-based assay. ORAC values are expressed as micromoles of Trolox equivalent per milligram of dry extract. $\mathrm{IC}_{50}$ values obtained using cell-based assay were expressed as the concentration inhibiting fifty percent of DCFH oxidation induced by tert-butyl hydroperoxide. The ORAC value and $\mathrm{IC}_{50}$ of the positive control, pycnogenol, are $5.4 \pm 0.3 \mu \mathrm{mol} \mathrm{TE} / \mathrm{mg}$ and $1.5 \pm 0.2 \mu \mathrm{g} / \mathrm{mL}$ respectively. All assays were conducted in triplicate, and the mean values are used. The vertical bars represent the standard deviation of each data point. Means within each group with different letters $(a-c)$ differ significantly $(p<0.05)$ from each other.

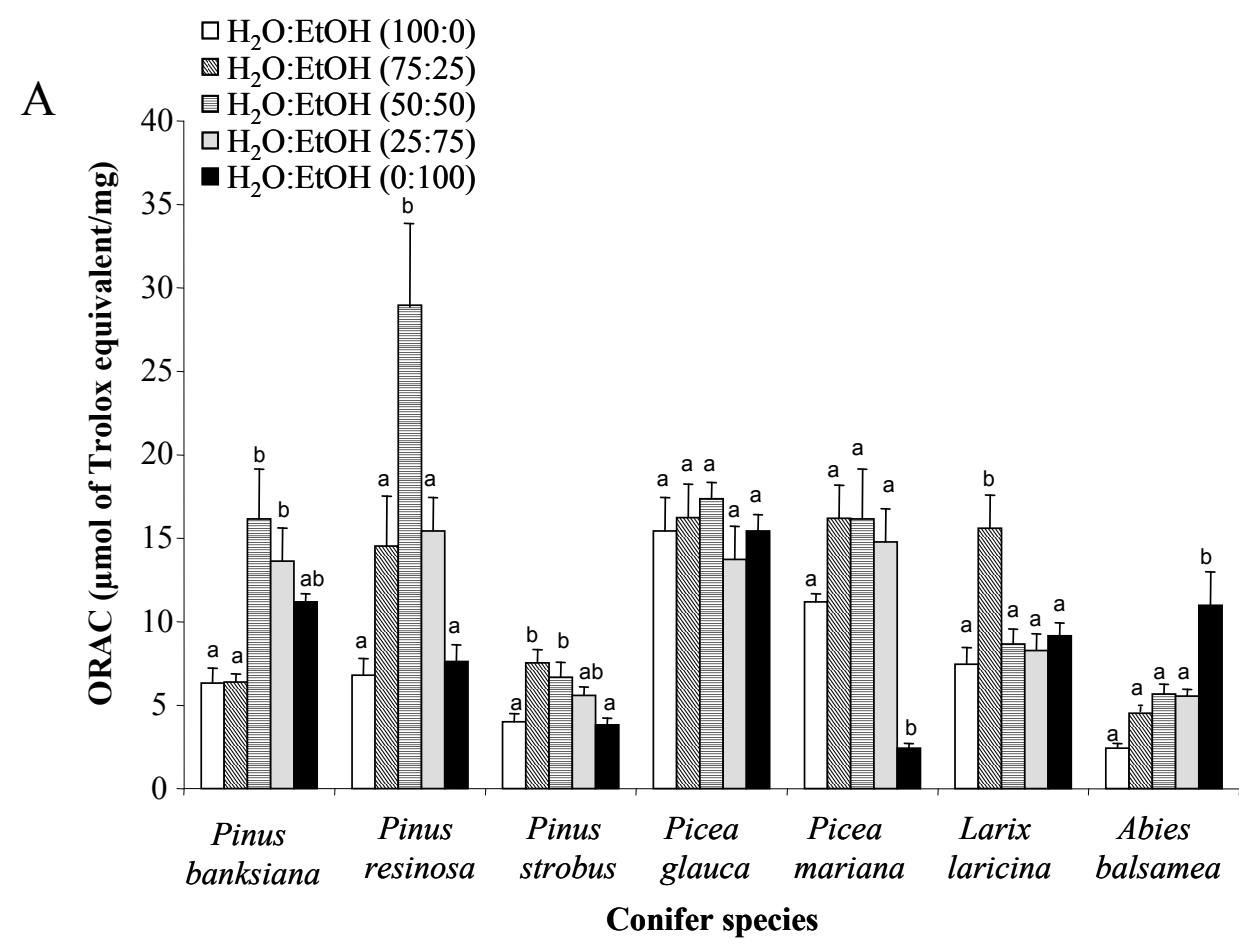


Figure 1. Cont.

B

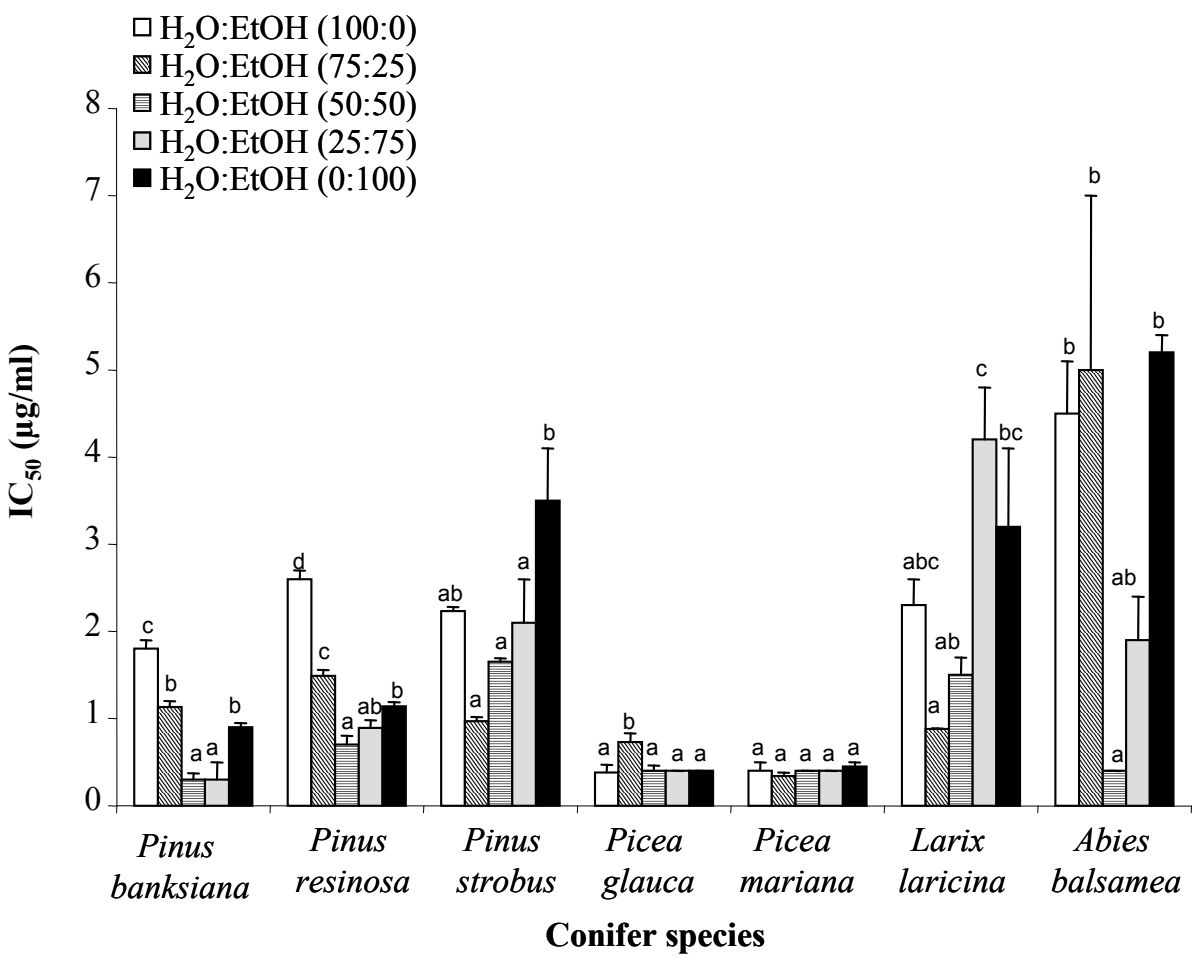

The antioxidant activity of bark extracts was analysed for each species in order to evaluate the best conditions of extraction. For Pinus banksiana, the water:ethanol extracts [50:50] and [25:75] possess the highest antioxidant activity in comparison with other conditions of extraction. The ORAC $\mathrm{FL}_{\text {values }}$ for Pinus banksiana-[50:50] and [25:75] are of $16 \pm 3 \mu \mathrm{mol} \mathrm{TE} / \mathrm{mg}$ and $14 \pm 2 \mu \mathrm{mol} \mathrm{TE} / \mathrm{mg}$, respectively, and their $\mathrm{IC}_{50}$ are of $0.30 \pm 0.07$ and $0.3 \pm 0.2 \mu \mathrm{g} / \mathrm{mL}$. Both extracts contain higher gallic acid equivalent phenolic concentrations with $37 \mathrm{~g} / 100 \mathrm{~g}$ for [50:50] extract and $45 \mathrm{~g} / 100 \mathrm{~g}$ for [25:75] extract. The most active extract of Pinus resinosa is the water:ethanol [50:50] with an ORAC value of $29 \pm 5 \mu \mathrm{mol} \mathrm{TE} / \mathrm{mg}$ and an $\mathrm{IC}_{50}$ of $0.7 \pm 0.1$. This extract is very rich in phenolic compounds, with $61 \pm 4 \mathrm{~g} \mathrm{GAE} / 100 \mathrm{~g}$, suggesting that phenolic compounds are in part responsible for the antioxidant activity. However, the [75:25] extract is also rich in phenolic compounds $(61 \pm 5 \mathrm{~g} / 100 \mathrm{~g})$ but significantly less active than the [50:50] extract. For Pinus strobus, no significant difference was found between the three most active conditions which include the water:ethanol [75:25], [50:50], and [25:75], with ORAC values ranging from 5.0 to $8.5 \mu \mathrm{mol} \mathrm{TE} / \mathrm{mg}$ and $\mathrm{IC}_{50}$ ranging from 0.91 to $2.7 \mu \mathrm{g} / \mathrm{mL}$. The total phenolic content is significantly correlated with cell-based assay but not with ORAC $_{\mathrm{FL}}$ values. The extracts of Picea glauca and Picea mariana possess similar antioxidant activities, using both assays. Indeed, the $\mathrm{ORAC}_{\mathrm{FL}}$ values ranged from 11 to $17 \mu \mathrm{mol} \mathrm{TE} / \mathrm{mg}$ and the $\mathrm{IC}_{50}$ ranged from 0.3 to $0.73 \mu \mathrm{g} / \mathrm{mL}$. The total phenolic contents of these extracts were also relatively high with concentrations ranging from $36 \mathrm{~g}$ to $59 \mathrm{~g}$ GAE/100 g. The Larix laricina-[75:25] possesses a significantly higher antioxidant activity in comparison with other conditions of extraction. For this extract, the $\mathrm{ORAC}_{\mathrm{FL}}$ value is $16 \mu \mathrm{mol} \mathrm{TE} / \mathrm{mg}$ and the $\mathrm{IC}_{50}$ is of $0.878 \mu \mathrm{g} / \mathrm{mL}$. However, the total phenolic content for all conditions tested are not significantly different with values ranging from $27 \pm 2 \mathrm{~g} \mathrm{GAE}$ to $34 \pm 2 \mathrm{~g} \mathrm{GAE} / 100 \mathrm{~g}$. For Abies balsamea, the highest antioxidant activity was obtained with water:ethanol [50:50] according to cell-based assay with $\mathrm{IC}_{50}$ of $0.3 \mu \mathrm{g} / \mathrm{mL}$. This extract 
is also significantly richer in phenolic compounds (32 g GAE/100 g) in comparison with other conditions of extraction. In contrast, the highest $\mathrm{ORAC}_{\mathrm{FL}}$ value was obtained with a [0:100] extract (11 $\mu \mathrm{mol} \mathrm{TE} / \mathrm{mg}$ ) which contained $20 \mathrm{~g}$ GAE of phenolic compounds by $100 \mathrm{~g}$ of extract.

Altogether, these results indicate that the total phenolic content do not always correlate with antioxidant activity. Therefore, the relationship between total phenolic content and $\mathrm{ORAC}_{\mathrm{FL}}$ and cell-based assay were analyzed.

\subsection{Relationship between Total Phenol Content and Antioxidant Activities}

The relationship between the total gallic equivalent phenolic contents and the antioxidant activity (ORAC $_{\mathrm{FL}}$ and cell-based assay) was determined by a Pearson correlation analysis for all conifer barks and conditions of extraction. Significant but moderate correlations were found between phenolic contents and ORAC as well as phenolic contents and cell based $\mathrm{IC}_{50}$ results, with correlation coefficient of $r=0.745(P<0.001)$ and $r=-0.670(P<0.001)$ respectively. Once the correlation was established between phenolic contents and antioxidant activities, their relation was described using linear regression analyses (Figure 2). The results show that even though phenolic content and antioxidant activity are related, their modest correlation and regression coefficients indicate that phenolic content may not explain totally the antioxidant activity when considering all extraction conditions. This suggests a change in the chemical composition of the extracts according to the solvent mixture used. Garcia-Perez et al. reported that the extracts obtained using ethanol maceration in comparison with hot water reflux contain lower total phenol content and higher concentration of hydroxycinnamic acids and proanthocyanidins [21]. In addition, antioxidant activity of ethanol extract was found decreased in comparison with hot water extract.

Figure 2. Relationship between (A) ORAC values and (B) $\mathrm{IC}_{50}$ values of extracts of conifer bark, and their content in phenolic compounds. Solid lines represent linear regression curves. The regression coefficient $\left(R^{2}\right)$ and the equation of curves are given.
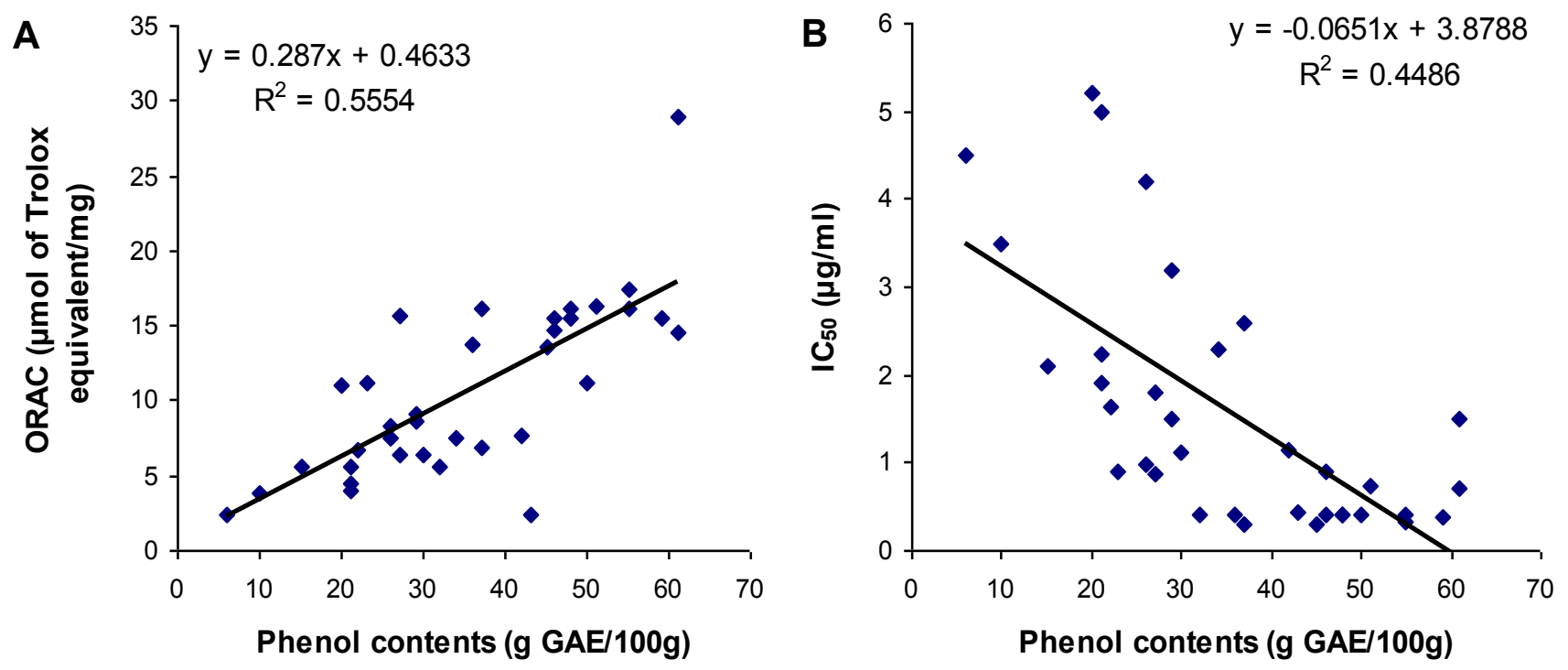
Native Americans used water infusion of conifer bark to relieve various ailments and diseases [1]. Therefore, water soluble phenolic compounds could be responsible for the activity of conifer bark. The relationship between total phenolic contents and activity of the bark extracts was determined again with Pearson correlation for all conifer species but this time including only water extracts. Both ORAC activity and cellular $\mathrm{IC}_{50}$ results were strongly correlated with phenolic contents, with a correlation coefficient of $r=0.9640(P<0.001)$ and $r=-0.9030(P=0.005)$ respectively. Both relations are shown by linear regression in Figure 3. These good correlations suggest that phenolic compounds could explain the activity of water extracts of all conifer species better than the activity measured including all extraction conditions. Also, the slightly lower correlation coefficient obtained with cellular assay results, in comparison with the correlation coefficients obtained with ORAC, corroborate the presumption that cellular context may measure activities that are not measurable with the strictly chemical ORAC assay.

Figure 3. Relationship between (A) ORAC values and (B) $\mathrm{IC}_{50}$ values of all water extracts of conifer bark, and their content in phenolic compounds. Solid lines represent linear regression curves. The regression coefficient $\left(R^{2}\right)$ and the equation of curves are given.
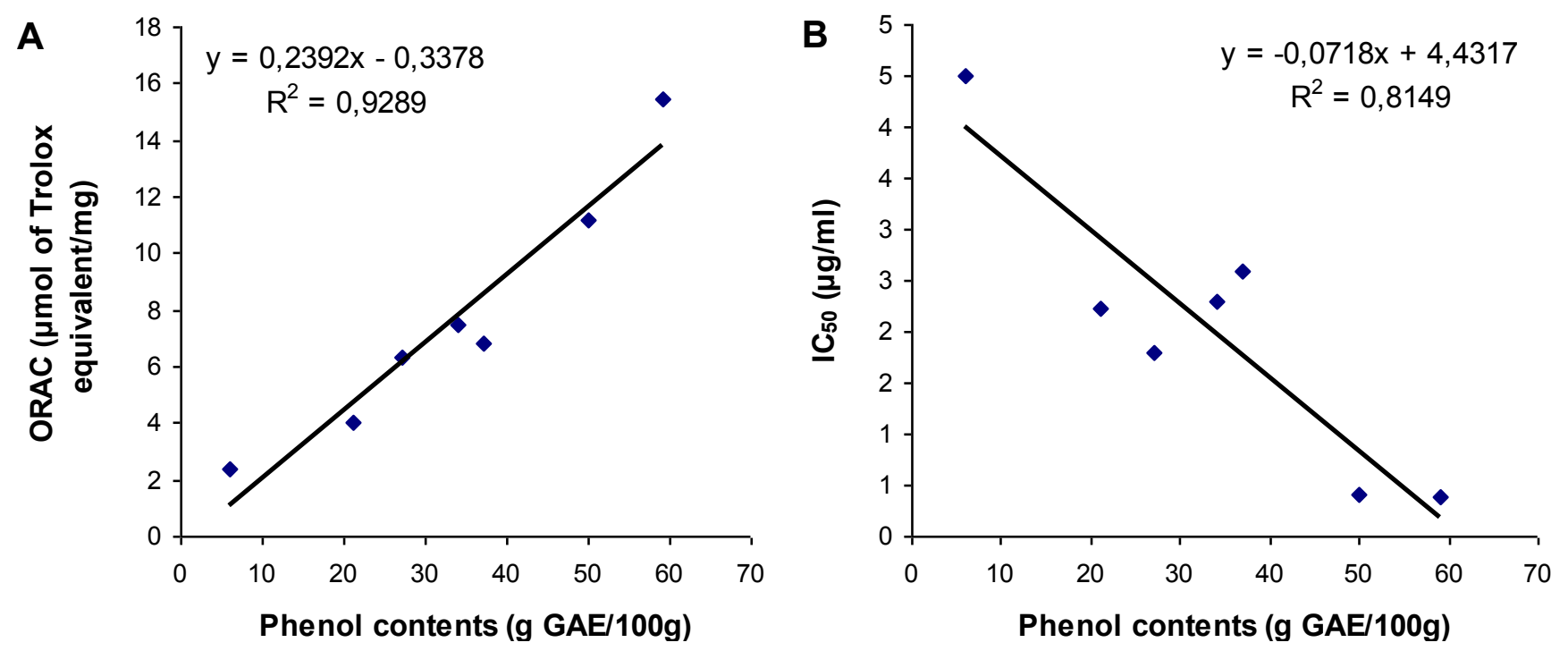

Considering only water extracts, Picea glauca and Picea mariana extracts possess the most significant $(P<0.05)$ total phenolic content and antioxidant activities in comparison with other species. Garcia-Pérez et al., also reported that hot water extract of Picea mariana bark are richer in phenolic compounds and also more antioxidant than bark extracts of Abies balsamea and Pinus banksiana [21]. In addition, Garcia-Pérez et al., have isolated and characterized most bioactive polyphenols in hot water extract of Picea mariana bark including trans-resveratrol which has a strong antioxidant activity [29]. On the other hand, water extracts of Picea glauca and Picea mariana possess, in comparison with Pycnogenol, similar concentration in phenolic compounds but are about 2 to 3 times more active considering ORAC values and about 3 times more active considering cell-based assay. Pinus banksianna, Pinus resinosa and Larix laricina possess similar antioxidant activity to Pycnogenol. Finally, Abies balsamea reveals lower antioxidant activity and total phenolic content. 


\section{Conclusions}

In conclusion, ultrasonic extraction of barks of boreal forest conifers yielded extracts that are not toxic, rich in phenolic compounds and having a strong antioxidant activity. Ultrasonic assisted extraction yields and phenolic contents of bark extracts from Picea mariana and Pinus banksiana were higher than those reported in literature using reflux and maceration extraction methods. Among the seven species studied, only bark extracts of Pinus resinosa, Picea glauca, and Picea mariana shown phenolic contents similar or higher than Pycnogenol, a standardized commercial extract from Pinus maritima bark. The best overall antioxidant activities with both cellular and ORAC assays were obtained with Picea glauca and Picea mariana, and appear to vary less in regard to extraction solvent conditions used. A good correlation between total phenolic content and antioxidant activity is found for all water extracts of barks, suggesting that phenolic compounds are responsible for the activity.

\section{Acknowlegments}

We thank Catherine Dussault for technical help and suggestions. The authors would like to thank Patrick Nadeau for plant identification. This work was supported by Action Concertée FQRNTFonds de la recherche forestière du Saguenay_Lac-Saint-Jean.

\section{Conflict of Interest}

The authors declare no conflict of interest.

\section{References}

1. Moerman, D.E. Native American Ethnobotany, 3rd ed.; Timber Press Inc.: Portland, OR, USA, 2000.

2. Chandler, R.F.; Freeman, L.; Hooper, S.N. Herbal remedies of the maritime indians. J. Ethnopharmacol. 1979, 1, 49-68.

3. Gottesfeld, L.M.J. The importance of bark products in the aboriginal economies of Northwestern British Columbia. Can. Econ. Bot. 1992, 46, 148-157.

4. Mechling, W.H. The malecite indians with notes on the micmacs. Anthropologica 1959, 8, 239-263.

5. Palmer, G. Shuswap Indian ethnobotany. Syesis 1975, 8, 29-51.

6. Reagan, A.B. Plants used by the bois fort chippewa (Ojibwa) Indians of Minnesota. Wis. Archeol. 1928, 7, 230-248.

7. Carr, L.G.; Westey, C. Surviving folktales \& herbal lore among the shinnecock Indians. J. Am. Folk. 1945, 58, 113-123.

8. Chapple, I.L. Reactive oxygen species and antioxidants in inflammatory diseases. J. Clin. Periodontol. 1997, 24, 287-296.

9. Nagata, M. Inflammatory cells and oxygen radicals. Curr. Drug Targets Inflamm. Allergy 2005, 4, 503-504.

10. Hitchon, C.A.; El-Gabalawy, H.S. Oxidation in rheumatoid arthritis. Arthritis Res. Ther. 2004, 6, 265-278.

11. MacNee, W. Pulmonary and systemic oxidant/antioxidant imbalance in chronic obstructive pulmonary disease. Proc. Am. Thorac. Soc. 2005, 2, 50-60. 
12. Repine, J.E.; Bast, A.; Lankhorst, I. Oxidative stress in chronic obstructive pulmonary disease: The Oxidative Stress Study Group. Am. J. Respir. Crit. Care Med. 1997, 156, 341-357.

13. Arts, I.C.W.; Hollman, P.C.H. Polyphenols and disease risk in epidemiologic studies. Am. J. Clin. Nutr. 2005, 81, 317S-325S.

14. Rahman, I.; Kilty, I. Antioxidant therapeutic targets in COPD. Curr. Drug Targets 2006, 7, 707-720.

15. Santus, P.; Sola, A.; Carlucci, P.; Fumagalli, F.; di Gennaro, A.; Mondoni, M.; Carnini, C.; Centanni, S.; Sala, A. Lipid peroxidation and 5-lipoxygenase activity in chronic obstructive pulmonary disease. Am. J. Respir. Crit. Care Med. 2005, 171, 838-843.

16. Tabak, C.; Arts, I.C.W.; Smit, H.A.; Heederik, D.; Kromhout, D. Chronic obstructive pulmonary disease and intake of catechins, flavonols, and flavones. Am. J. Respir. Crit. Care Med. 2001, 164, 61-64.

17. Packer, L.; Rimbach, G.; Virgili, F. Antioxidant activity and biologic properties of a procyanidin-rich extract from pine (Pinus maritima) bark, pycnogenol. Free Radic. Biol. Med. 1999, 27, 704-724.

18. Devaraj, S.; Vega-López, S.; Kaul, N.; Schönlau, F.; Rohdewald, P.; Jialal, I. Supplementation with a pine bark extract rich in polyphenols increases plasma antioxidant capacity and alters the plasma lipoprotein profile. Lipids 2002, 37, 931-934.

19. Lau, B.H.; Riesen, S.K.; Truong, K.P.; Lau, E.W.; Rohdewald, P.; Barreta, R.A. Pycnogenol as an adjunct in the management of childhood asthma. J. Asthma 2004, 41, 825-832.

20. Diouf, P.N.; Stevanovic, T.; Cloutier, A. Study on chemical composition, antioxidant and anti-inflammatory activities of hot water extract from Picea mariana bark and its proanthocyanidin-rich fractions. Food Chem. 2009, 113, 897-902.

21. García-Pérez, M.-E.; Royer, M.; Duque-Fernandez, A.; Diouf, P.N.; Stevanovic, T.; Pouliot, R. Antioxidant, toxicological and antiproliferative properties of Canadian polyphenolic extracts on normal and psoriatic keratinocytes. J. Ethnopharmacol. 2010, 132, 251-258.

22. Royer, M.; Prado, M.; Garcia-Pérez, M.-E.; Diouf, P.N.; Stevanovic, T. Study of nutraceutical, nutricosmetics and cosmeceutical potentials of polyphenolic bark extracts from Canadian forest species. PharmaNutrition 2013, in press.

23. Singleton, V.L.; Rossi, J.A. Colorimetry of total phenolics with phosphomolybdic-phosphotungstic acid reagents. Am. J. Enol. Vitic. 1965, 16, 144-158.

24. Ou, B.; Hampsch-Woodhill, M.; Prior, R.L. Development and validation of an improved oxygen radical absorbance capacity using fluorescein as the fluorescent probe. J. Agric. Food Chem. 2001, 49, 4619-4626.

25. Girard-Lalancette, K.; Pichette, A.; Legault, J. Sensitive cell-based assay using DCFH oxidation for the determination or pro- and antioxidant properties of compounds and mixtures: Analysis of fruit and vegetable juices. Food Chem. 2009, 115, 720-726.

26. O'Brien, J.; Wilson, I.; Orton, T.; Pognan, F. Investigation of the Alamar Blue (resazurin) fluorescent dye for the assessment of mammalian cell cytotoxicity. Eur. J. Biochem. 2000, 267, 5421-5426.

27. Ustun, O.; Senol, F.S.; Kurkcuaglu, M.; Orhan, I.E.; Kartal, M.; Can Baser, K.H. Investigation on chemical composition, anticholinesterase and antioxidant activities of extracts and essential oils of Turkish Pinus species and pycnogenol. Ind. Crop. Prod. 2012, 38, 115-123. 
28. Dudonné, S.; Vitrac, X.; Coutière, P.; Woilles, M.; Mérillon, J.-M. Comparative study of antioxidant properties and total phenolic content of 30 plant extracts of industrial interest using DPPH, ABTS, FRAP, SOD, and ORAC Assays. J. Agric. Food Chem. 2009, 57, 1768-1774.

29. García-Pérez, M.-E.; Royer, M.; Herbette, G.; Desjardins, Y.; Pouliot, R.; Stevanovic, T. Picea mariana bark: A new source of trans-resveratrol and other bioactive polyphenols. Food Chem. 2012, 135, 1173-1182.

(C) 2013 by the authors; licensee MDPI, Basel, Switzerland. This article is an open access article distributed under the terms and conditions of the Creative Commons Attribution license (http://creativecommons.org/licenses/by/3.0/). 